\title{
ASSESSMENT OF PREGNANT'S OBSTACLES TOWARD ANTENATAL CARE IN MOSUL
}

\section{Article information}

Article history:

Received April 5, 2020

Accepted June 14, 2020

Available online June , 28, 2020

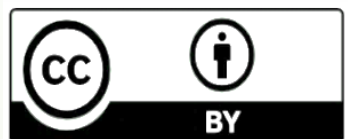

DOI: 10.33899/mjn.2020.164620, College of Nursing, University of Mosul

Creative Commons Attribution 4.0 International License

(https://mjn.mosuljournals.com/article_164620.html)

\section{Omar Hussein Abdulla ${ }^{1}$}

Waleed Ghanim Ahmad ${ }^{2}$

\section{Abstract}

Background: Antenatal care is the routine health program of pregnant women to reduce the risk of stillbirths and pregnancy complications and give women a positive pregnancy experience.

Objectives: This study aims to assess the utilization ratio of antenatal care services and to identify current barriers to proper utilization of antenatal care services in Mosul city. Subjects and methods: A descriptive study was carried out during the period from 26 September, 2019 to $1^{\text {st }}$ April 2020. The study has been conducted among three hospitals in Mosul city namely: Al- Khanssa teaching hospital, Al- Salam teaching hospital and Al-Batool teaching hospital. The target population was pregnant women who attend maternity and child care unit. The study sample consists of 300 pregnant women. Data collection tool was composed of (2) main parts. The first one was for socio demographic data about the pregnant woman. The second part was for gynecological, obstetric and antenatal care characteristics. It was constructed through use of (2) option- type (yes-no). Content validity was determined by presenting the items to a panel of scientific experts.

Results: study results revealed that $84 \%$ of studied women were found to have regular antenatal care visits. Regarding obstacles to antenatal care, far distance from the centre was found among $52 \%$ of study subjects.

Recommendations: The study recommends establishing several antenatal care clinics in different areas of Mosul city to improve medical and nursing staff caring attitude in addition to increasing people' $\mathrm{s}$ awareness through health education about the importance of conducting antenatal care visits since the beginning of pregnancy.

Key words: Antenatal care, Obstacles, Utilization, Mosul

${ }^{1}$ B.Sc.N.MSN. candidate

${ }^{2}$ Assistant Professor, PhD. Community Medicine, College of Medicine, University of Mosul, Iraq 


\section{INTRODUCTION}

Antenatal care is a chance to present a positive degree pregnancy experience and to improve maternal survival. Caution consideration in the antenatal period is additionally significant for supporting the long time growth and development of the child as its piece of the basic care and monitoring for complications (Kuhnt \& Vollmer 2017). Antenatal care also includes consideration during pregnancy. It is a type of preventive medicine. The point is to give occasional registration that enables specialists and birth assistants to treat and avoid potential medical issues during pregnancy and advance solid ways of life that have advantage to mother (National__Library of Medicine,(2012). During antenatal examinations, the pregnant woman receives the necessary health facts on different kinds of changes during pregnancy especially physiological and biological ones as well as prenatal nutrition including vitamins. They are also given some recommendations on therapeutic measures and changes to better health lifestyles. Routine care services available during pregnancy including prenatal testing and diagnosis - significantly reduce maternal mortality, spontaneous abortion, birth defects, low birth weight babies, and childhood infections (Medicine Net, 2011).

The first antenatal care visit provides a chance to review or assess medical, family, reproductive, nutritional, genetic and psychosocial histories, Women with prior cesarean delivery for the recurrent pregnancies (HACKER \&MOORE'S 2010).

Antenatal care including care during maternity, should start from the first degree of gestation. Charwoman have an accessibility to antenatal care services either from wellness doer during their domiciliary visits or by visiting a wellness center where such services are available Filling information and advising to women about pregnancy-related complications and possible curative bar for the early detection and management of complications is one of the most important components of antenatal care (Chandhiok, et. al, 2006).

\section{SUBJECTS AND METHODS}

Adescryiptive cross sectional study design has been adopted. The study has been conducted among three major maternity teaching hospitals in Mosul. These hospitals are Al-khansaa, Alsalam and Al-batool teaching hospitals. Al-batool Teaching Hospital lies at the 
right side of Mosul city and Alkhansaa Teaching Hospital is located in the northeast region at the left side of Mosul city, Al-salam Teaching Hospital is located in the southeast region at the left side of Mosul city. Study subjects were 300 pregnant women chosen randomly from daily attendants of the consultation maternity

\section{RESULTS}

Table (1) Frequency distribution of the study population according to socio demographic characteristics.

\begin{tabular}{|c|c|c|c|c|c|}
\hline \multicolumn{2}{|c|}{ Socio demographic parameter } & \multirow{2}{*}{$\begin{array}{c}\mathrm{N}=300 \\
36\end{array}$} & \multirow{2}{*}{$\begin{array}{c}\% \\
12 \%\end{array}$} & \multirow{2}{*}{$\begin{array}{c}\mathrm{X}^{2} \\
89.947\end{array}$} & \multirow{2}{*}{$\begin{array}{c}\text { P. value } \\
0.000\end{array}$} \\
\hline Age group & $<18$ & & & & \\
\hline & $18-24$ & 143 & $48 \%$ & & \\
\hline & $>24-30$ & 70 & $23 \%$ & & \\
\hline & $>30$ & 51 & $17 \%$ & & \\
\hline \multirow[t]{4}{*}{ Educational level } & Illiteracy & 74 & $25 \%$ & 126.667 & 0.000 \\
\hline & primary school & 127 & $42 \%$ & & \\
\hline & Secondary school & 55 & $18 \%$ & & \\
\hline & University education & 43 & $15 \%$ & & \\
\hline \multirow[t]{3}{*}{ Residence } & Urban & 239 & $80 \%$ & 294.020 & 0.000 \\
\hline & Rural & 45 & $15 \%$ & & \\
\hline & Some urban & 15 & $5 \%$ & & \\
\hline \multirow[t]{4}{*}{ Parent's Education } & Illiteracy & 79 & $26 \%$ & 172.033 & 0.000 \\
\hline & primary school & 141 & $47 \%$ & & \\
\hline & Secondary school & 30 & $10 \%$ & & \\
\hline & University education & 50 & $17 \%$ & & \\
\hline \multirow[t]{2}{*}{ Type of family } & Extended & 249 & $83 \%$ & 130.680 & 0.000 \\
\hline & Nuclear & 51 & $17 \%$ & & \\
\hline \multirow[t]{2}{*}{ Husband's job } & Employee & 65 & $22 \%$ & 96.333 & 0.000 \\
\hline & un employee & 235 & $78 \%$ & & \\
\hline \multirow[t]{2}{*}{ Pregnant's job } & Employee & 27 & $9 \%$ & & \\
\hline & Housewife & 273 & $91 \%$ & & \\
\hline \multirow[t]{4}{*}{ Economic income } & Less than 300 & 231 & $77 \%$ & 201.720 & 0.000 \\
\hline & $\begin{array}{l}\text { 301- } 600 \text { thousands } \\
\text { dinar }\end{array}$ & 51 & $17 \%$ & & \\
\hline & $\begin{array}{c}>601-900 \text { thousand } \\
\text { dinar }\end{array}$ & 15 & $5 \%$ & & \\
\hline & > 901-1 million & 3 & $1 \%$ & & \\
\hline \multirow[t]{3}{*}{ Cigarette smoking } & Smoker & 0 & $0 \%$ & 0.000 & 1.000 \\
\hline & Non smoker & 300 & $100 \%$ & & \\
\hline & $\mathrm{X}$ smoker & 0 & $0 \%$ & & \\
\hline \multirow[t]{2}{*}{ Husband's smoking } & Yes & 103 & $34 \%$ & 29.453 & 0.000 \\
\hline & No & 197 & $66 \%$ & & \\
\hline
\end{tabular}




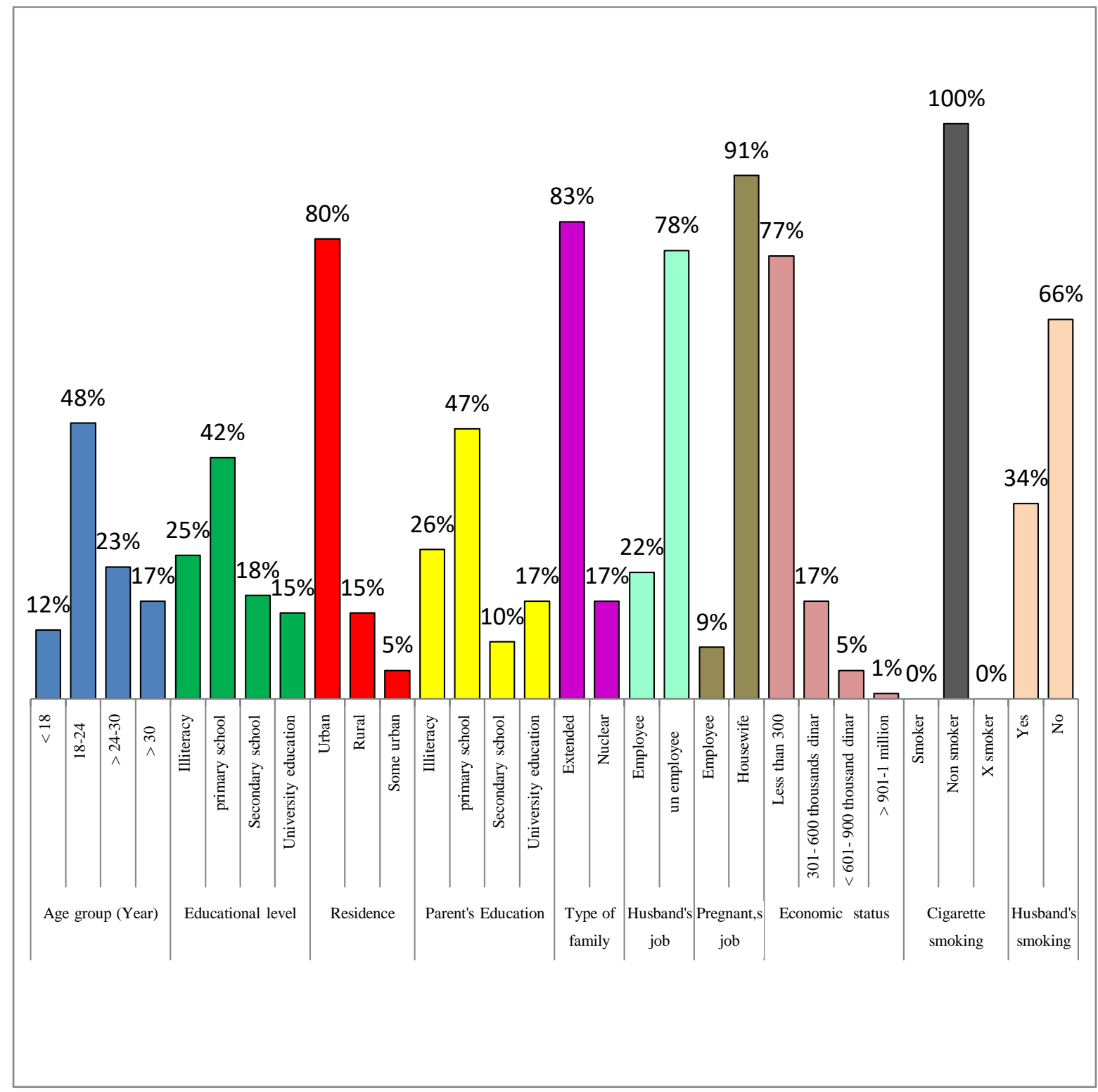

Figure (1) histogram showing frequency distribution of the study population according to socio demographic characteristics. 
Table (2) Frequency distribution of study population according to antenatal care visits parameter.

\begin{tabular}{|c|c|c|c|c|c|}
\hline \multicolumn{2}{|c|}{ Antenatal care visits parameter } & \multirow{2}{*}{$\begin{array}{l}\mathrm{N}=300 \\
247\end{array}$} & \multirow{2}{*}{$\begin{array}{l}\% \\
82 \%\end{array}$} & \multirow{2}{*}{$\begin{array}{l}\mathrm{X}^{2} \\
125.453\end{array}$} & \multirow{2}{*}{$\begin{array}{r}\mathrm{P} \\
0.000\end{array}$} \\
\hline Antenatal care visit & present & & & & \\
\hline & abscent & 53 & $18 \%$ & & \\
\hline \multirow{3}{*}{$\begin{array}{l}\text { No. of visits per } \\
\text { month }\end{array}$} & 1 & 206 & $83 \%$ & 279.992 & 0.000 \\
\hline & 2 & 28 & $12 \%$ & & \\
\hline & 3- above & 13 & $5 \%$ & & \\
\hline \multirow[t]{2}{*}{ regularity of visit } & Regular & 207 & $84 \%$ & 112.911 & 0.000 \\
\hline & Irregular & 40 & $16 \%$ & & \\
\hline \multirow{3}{*}{$\begin{array}{l}\text { If regular, when was } \\
\text { your first visit to the } \\
\text { primary health center }\end{array}$} & $\begin{array}{l}\text { Since beginning of } \\
\text { pregnancy }\end{array}$ & 82 & $40 \%$ & 77.594 & 0.000 \\
\hline & during ${ }^{2 n d}$ trimester & 113 & $54 \%$ & & \\
\hline & during $3^{\text {rd }}$ trimester & 12 & $6 \%$ & & \\
\hline \multirow{2}{*}{$\begin{array}{l}\text { Health education } \\
\text { advice during } \\
\text { antenatal care visits }\end{array}$} & Received & 239 & $97 \%$ & 216.036 & 0.000 \\
\hline & Not received & 8 & $3 \%$ & & \\
\hline \multirow{2}{*}{$\begin{array}{l}\text { If yes, who is the } \\
\text { source of information }\end{array}$} & Physician & 57 & $24 \%$ & 135.879 & 0.000 \\
\hline & Nurse & 50 & $21 \%$ & & \\
\hline \multirow{2}{*}{$\begin{array}{l}\text { During each visit was } \\
\text { there any laboratory } \\
\text { investigations done }\end{array}$} & present & 290 & $97 \%$ & 261.333 & 0.000 \\
\hline & abscent & 10 & $3 \%$ & & \\
\hline
\end{tabular}




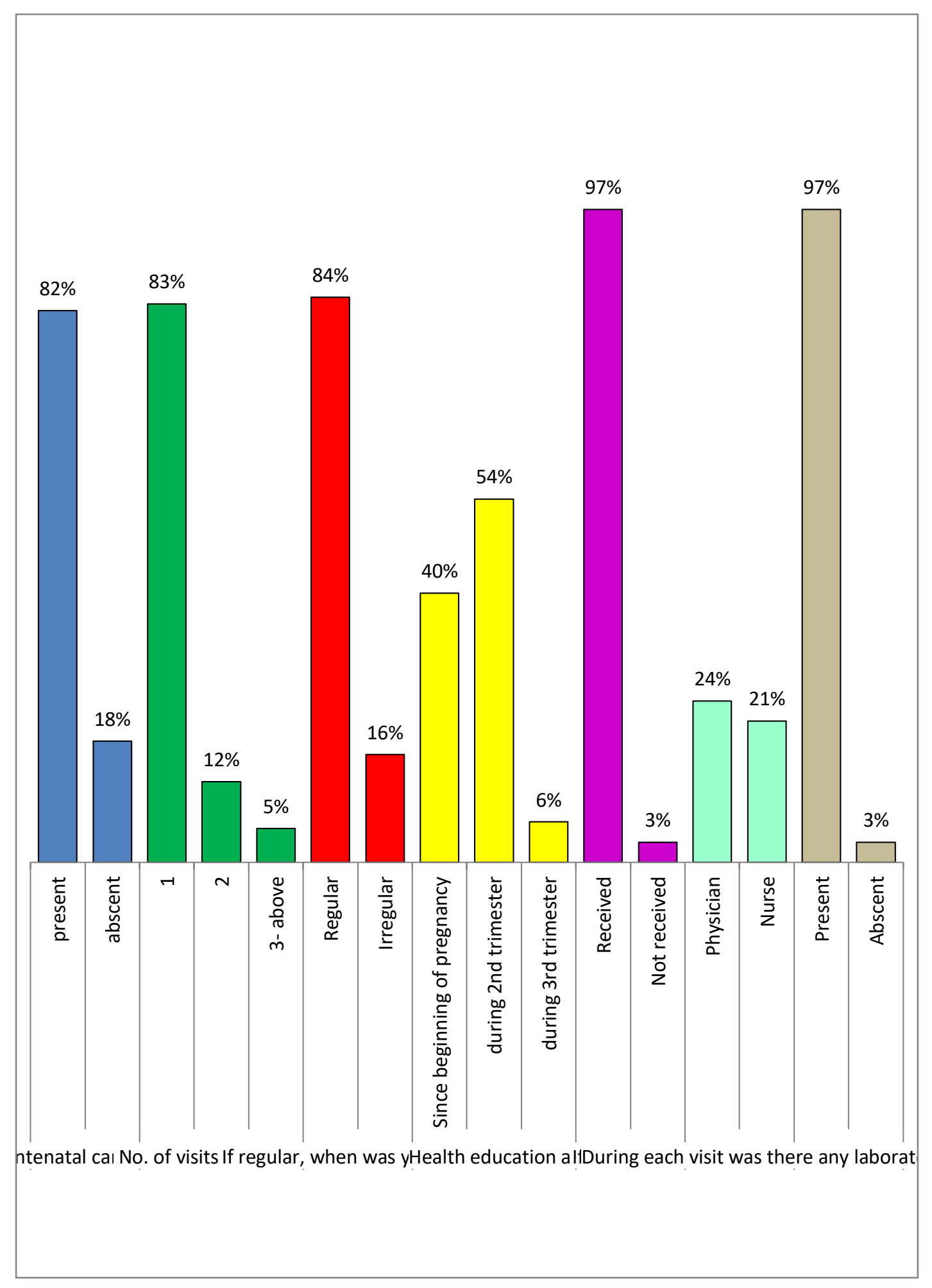

Figure (2) histogram showing frequency distribution of study population according to antenatal care visits parameter. 
Mosul Journal of Nursing, Vol. 8, No. 1, 2020 ( 32-41 )

Table (3) Frequency distribution of studied women according to type of obstacles against antenatal care visits.

\begin{tabular}{|c|c|c|c|c|}
\hline Obstacles against antenatal care visits & $\mathrm{N}=300$ & $\%$ & $x^{2}$ & $\mathrm{P}$ \\
\hline Long distance between the center and dwelling & 157 & $52 \%$ & & \\
\hline No enough time & 19 & $6 \%$ & & \\
\hline Low economic status & 70 & $23 \%$ & & \\
\hline Social problem inside family & 77 & $26 \%$ & & \\
\hline Psychological problems & 12 & $4 \%$ & & \\
\hline $\begin{array}{l}\text { I beleive I'm healthy. No need to attend the antenatal } \\
\text { clinic }\end{array}$ & 25 & $8 \%$ & & \\
\hline Daily business (type of work). & 11 & $4 \%$ & 0.846 & 0.924 \\
\hline Fear from vaccination and investigation & 23 & $8 \%$ & & \\
\hline Family / husband refuse conduction visits & 33 & $11 \%$ & & \\
\hline Unsatisfactory ( poor) antenatal care & 61 & $20 \%$ & & \\
\hline Careless attitude of physician and nurses & 88 & $29 \%$ & & \\
\hline I don't trust in antenatal care & 36 & $12 \%$ & & \\
\hline Unavailability of investigation & 36 & $12 \%$ & & \\
\hline
\end{tabular}




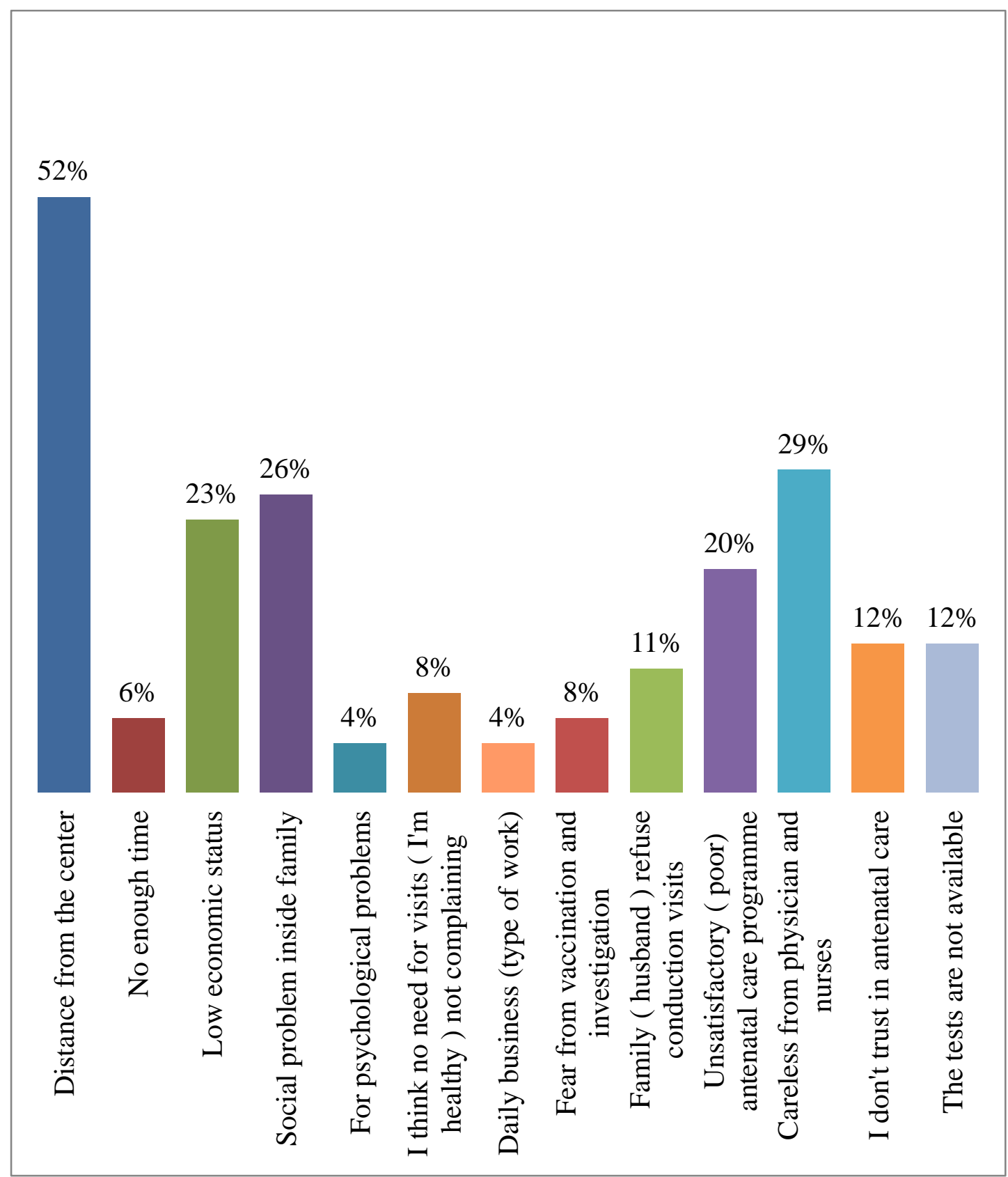

Figure (3) histogram showing frequency distribution of studied women according to type of obstacles against antenatal care visits.

\section{DISCUSSION}

Rgarding the education level of pregnant women, It is found that about $42 \%$ of them are graduated from primary schools, while only $17 \%$ of them are university graduates. In contrast to a study done in Indonesia reported that mothers with high level of education had the highest utilization rate for antenatal care use. This finding of a study by (Erlindawati et. al, 2008) indicating that education has an impact on awareness among the population and their use of health services. As far as pregnant's job, $91 \%$ were housewife which is 
consistent with Shahjahan et. al., 2012 in which $95.6 \%$ of pregnant women were found housewives. The majority of the sample is in the 24-30 years age group. This proportion reflects Mosul population habits that make the woman ready for marriage after completing the age of twenty. The majority of the interviewed woman found having low economic income $(77 \%)$. High income mothers had the highest percentage use of antenatal care services compared to those with a lower family-income (Rahman et.al, 2010).

As for the number of visits per month, the study showed that $83 \%$ of pregnants visit

\section{CONCLUSIONS \& RECOMMENDATIONS}

Relative underutilization of antenatal care services is found in Mosul. The most common obstacles are long distance from the center, family social problem and careless attitude of physician and nurses. Continuous educational programs are necessary to improve nurses attitude toward antenatal care to pregnant women. Holding educational symposiums to overcome the social problems facing the pregnant woman is an urgent necessity.

\section{REFERENCES}

Erlindawati, Chompikul J, Isaranurug S. Factors related to the utilization of antenatal care services among pregnant women at health centers in Aceh Besar district, Nanggroe Aceh Darussalam province, Indonesia. J Public Health Dev 2008; 6:99- 108. maternity units per month. This agrees with the finding of another study done in Vietnam in which $96.6 \%$ of pregnant women visit antenatal care unit per month (Sepehri et.al., 2008).

As far as obstacles against antenatal care visits, study results revealed that the top obstacles are living far from the center, social problem inside family and careless attitude of physician and nurses. Similar results have been found in a study conducted in Nigeria which found that $48.8 \%$ of the pregnant women did not attend antenatal care services because the providers were far from them (Osungbade et.al., 2011).

Chandhiok N, Dhillon BS, Kambo I, Saxena NC. Determinants of antenatal care utilization in rural areas of India: a cross-sectional study from 28 districts (an ICMR task force study). J Obstet Gynecol India 2006; 56:47-52.

Definition of Prenatal care". Medicine Net, Inc. 27 Apr 2011

HACKER \&MOORE'S (2010): Essential of OBSTETRICS and GYNECOLOGY, china. Elsevier, library of congress cataloging, 9 th ed. P: 86

Kuhnt, J., \& Vollmer, S. (2017). Antenatal care services and its implications for vital and health outcomes of children: evidence from 193 surveys in 69 low-income and middle-income countries. BMJ open, 7(11), 017122.

Osungbade, K. O., \& Ige, O. K. (2011). Public health perspectives of preeclampsia in developing countries: implication for health system strengthening. Journal of pregnancy, 2011.

Prenatal Care" (2012). U.S. National Library of Medicine. 22February 
Mosul Journal of Nursing, Vol. 8, No. 1, 2020 ( 32-41 )

Rahman M, Islam R, Rahman M. Antenatal care seeking behaviour among slum mothers. A Study of Rajshahi City Corporation, Bangladesh. SQU Med J 2010; 10:50-6.

Sepehri, A., Moshiri, S., Simpson, W., \& Sarma, S. (2008). Taking account of context: how important are household characteristics in explaining adult health-seeking

behaviour? The case of

Vietnam. Health policy and planning, 23(6), 397-407.

Shahjahan et al. (2012) Antenatal care services in rural Bangladesh South East Asia Journal of Public Health 2(2):61-66. 